\title{
"A good deal about California does not, on its own preferred terms, add up": Joan Didion between Dawning Apocalypse and Retrogressive Utopia
}

Eva-Sabine Zehelein

\section{(2) OpenEdition Journals}

Electronic version

URL: https://journals.openedition.org/ejas/9324

DOI: 10.4000/ejas.9324

ISSN: 1991-9336

Publisher

European Association for American Studies

Electronic reference

Eva-Sabine Zehelein, "'A good deal about California does not, on its own preferred terms, add up": Joan Didion between Dawning Apocalypse and Retrogressive Utopia", European journal of American studies [Online], 6-3 | 2011, document 6, Online since 27 September 2011, connection on 08 July 2021. URL: http://journals.openedition.org/ejas/9324 ; DOI: https://doi.org/10.4000/ejas.9324

This text was automatically generated on 8 July 2021 .

Creative Commons License 


\title{
"A good deal about California does not, on its own preferred terms, add up": Joan Didion between Dawning Apocalypse and Retrogressive Utopia
}

\author{
Eva-Sabine Zehelein
}

\section{Introduction}

1 Raking through the smallish heap of critical leaves which have gathered over and around the (still growing) oeuvre of Joan Didion, one is quickly au fait with the fact that some leaves are very fresh, yet most of them are either brittle-dry or rather rotten. It is quite astonishing that despite a certain element of undeniable jouissance, Didion's critical reception still proves to be quite below par, despite some scholars' claim that "her canonical status is becoming more assured" (Felton, Introduction 1). A few representative specimen shall serve to illustrate this point.

Barbara Grizzuti Harrison could certainly lay claim to the most colorful example of irritating confusions. Jouissance and-to a certain degree-amusing outrage characterize her notorious essay "Joan Didion: Only Disconnect." Calling Didion a "neurasthenic Cher" whose "lyrical angst strikes me as transparently ersatz," and whose "subject is always herself," Harrison claims that "Didion's 'style' is a bag of tricks." For Harrison, "Didion uses style as argument" and "makes it a point of honor not to struggle for meaning." It is rather annoying to see how shamelessly Harrison (ab)uses Didion as a wailing wall for her vague woes which obviously derive from other sources than Joan Didion's literary work. Harrison's essay disintegrates into a railing tirade, devoid of any serious literary exegesis which, to the reader's utter embarrassment, reveals much more about its author than about the alleged subject. To use her own words, Harrison, 
and not Didion, "is the lyricist of the irrational. Some people find that charming. I do not" (Harrison 116). Her judgment is misguided, because it obliterates from view the intricate interaction between Didion's own psyche and America as she observes it. The following analysis will show that this is how Didion asserts her literary skills and symbolic sumptuousness.

Well tuned to literary criticism's vogues, approaches and perspectives applied to Didion's texts-to highlight their strategies, themes and meanings-have changed over the decades. We find, among others, the occasional existentialist (Geherin), the belated New Critic (Hollowell), and, mixed in, the inevitable feminist. For example, Janis P. Stout's study Strategies of Reticence: Silence and Meaning in the Works of Jane Austen, Willa Cather, Katherine Anne Porter, and Joan Didion assembles a motley bunch of authors, and unfortunately culminates in bleak statements such as: "Didion hurls silence back into the face of patriarchy" (23). The bulk of these "lit.crit. leaves" have by now reached an advanced state of intellectual fermentation, and can thus be raked aside.

4 Fresh and illuminating insights into Didion's writing have been brought forth occasionally by works using the cultural studies tool kit. Jennifer Brady's 1979 essay "Points West, Then and Now: The Fiction of Joan Didion" draws on Frederick Jackson Turner's frontier thesis to establish a very pertinent point: Didion is preoccupied with the socio-cultural, not to say mythical, topos of the American West. I second the notion that the West in general and California in particular indeed form an omnipresent theme in Didion's art. "Some Dreamers of the Golden Dream" have "run out of continent" (Slouching 172), and even the "Girl of the Golden West" has in idiosyncratic manner "cut her losses and headed west" (After Henry 103), paying heed to the advice provided by an emigrant's diary of 1850: "Never take no cutoffs and hurry along as fast as you can" (After Henry 107; Where I Was From 75).

\section{America's Highly Personal Cultural/Literary Historian}

5 Never has Didion been more outspoken about her genuine subject matter and key concern than in her 2003 publication Where I Was From. Not only is the title more than indicative. Addressing the reader, Didion explicitly states:

[...] this book represents an exploration into my own confusions about the place and the way in which I grew up, confusions as much about America as about California, misapprehensions and misunderstandings so much a part of who I became that I can still to this day confront them only obliquely. (18)

This essay sets out to illustrate some facets of Didion's rich writing, based on the claim that Joan Didion is America's highly personal cultural/literary historian, and one of the most gifted and perceptive authors of and on California and the American West. The most rewarding approach for illuminating the interpretive core of her self-referential writing seems to be the identification of that mental landscape, that interaction between her own personal emotions and the American (mythical) landscape, where she brings into play sometimes obvious, sometimes more subtle references to American ideas and ideals. While others have wrestled with issues of race, gender and class, Didion has, throughout her literary career, struggled with what one might call the "sense of place" and the "spirit of place"-echoing among others Frederick Jackson 
Turner as a notorious epitome of the mythologizing of the American West. In "Girl of the Golden West," Didion lucidly remarks:

The extent to which certain places dominate the California imagination is apprehended, even by Californians, only dimly. Deriving not only from the landscape but from the claiming of it, from the romance of emigration, the radical abandonment of established attachments, this imagination remains obdurately symbolic, tending to locate lessons in what the rest of the country perceives only as scenery. (After Henry 100)

7 And California is, indeed, not an actual geographical location, such as La Scala in Beverly Hills, or Ernie's in San Francisco, or Chez Panisse in Berkeley, but "somewhere else." It is a destination which "flickers chimerically on the horizon, ever receding, ever diminishing" ("Notes from a Native Daughter," Slouching 171). It is the ingenious fusion of the crossing stories and the depictions of the process of settlement, of taking possession of that particular land "where we run out of continent" (Slouching 172), which has created a distinct California, an image and a concept, through automythology. Incessantly, Didion reflects upon this peculiarly Californian image-concept, on the specificity of regional attachment, and on the meaning of the American West/ California for the nation as a whole. Deliberately and sometimes nearly violently, she clashes her understanding of the fictional(ized) West-as-myth in the canonized fashion of promise, redemption and rebirth, of being the "last good place," the "golden land" and the "fresh start for the Americans," with (f)actual reports of developments she perceives. These instances seem to betray the notion that California is in any way (still) in tune with its own superimposed image. Her observations illustrate that California is not-or no longer-the exceptional, the redeeming space, but bears symptoms of a universal development in American culture and society. And for Didion, that is a process of degeneration and disintegration.

\section{Between Dawning Apocalypse and Retrogressive Utopia}

8 Didion's 1968 essay collection Slouching Towards Bethlehem, and the more recent programmatic publication Where I Was From (2003) are both perfect examples of the mechanisms which underlie Didion's reportage-like texts, namely the subcutaneous opposition between dawning apocalypse and retrogressive utopia manifested in descriptions, visualizations and instrumentalizations of (internal) landscapes. Before the backdrop of the craved idea(l), reality makes the writer cringe; it is the discrepancy and intrinsic tension between the real and the imagined or idea(l) which causes the omnipresent Weltschmerz of Didon's work. Instead of reverting to Jean Baudrillard's idiosyncratic notions of "Ravishing hyperrealism" (America 31), I strongly recommend reading Joan Didion. Built on constitutive ideas and concepts of American selfunderstanding and self-definition, she has created her personalized version of a retrogressive utopia, and, concurrently, she has an inkling of a dawning apocalypse. It is through this technique of juxtaposition between real and ideal that Didion can voice her hunch that "California is," as Charles Isherwood once remarked, "a tragic landlike Palestine, like every promised land" (qtd. in Michaels, Reid, and Scherr 309).

On an additional level of her narratives, Didion's depictions of actual place construct yet another metaphorical space. The geographical realities of the Western American 
states, and in particular of California, her home state, transform into an internal, a psychological, landscape. Didion's perception of the West is colored by a very personal and idiosyncratic sensitivity to her surroundings, intertwined with a sentimentalnostalgic image of the nature, history, character and meaning of the American West as a cultural topos. In her works, reminiscent of what is generally labeled "New Journalism," her chronicles of American life are always closely linked to her own self and psyche. Her descriptions of California and the West are seismographs of her own confusions, moments of disorientation, insecurity, and loss. Didion is therefore one of those exceptional writers, who, in her fictionalized reportages, comments on American reality, ideas, and her own predicament; she is, indeed, in situ. Identity and landscape fuse into auto-psychoanalysis, culminating in the final revelation that "there is no real way to deal with everything we lose" (Where I Was From 225).

The essay collection Slouching Towards Bethlehem (1968) has continuously been misinterpreted. Particularly the title essay has too often been read as a quasidocumentary comment on American youth culture of the 60's, reducing it to anadmittedly intelligent-concoction of documentary fact and narrative fiction, maybe even an informal essay à la Montaigne's "C'est moi que je peins." Time and again, both the essay "Slouching Towards Bethlehem" and the collection have ever so effortlesslyand with a gasp of relief- been pigeonholed as merely another piece of New Journalism. ${ }^{2}$ Insights such as Chris Anderson's have been rare; Anderson has argued that,

Her characteristic strategy is to reflect on contemporary life from the standpoint of her own experience or to engage in autobiographical narrative which ultimately

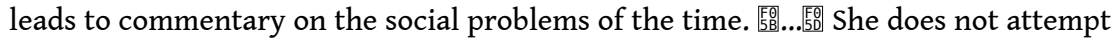
the 'saturation reporting' that distinguishes the New Journalism, and her presentation of fact is almost a point of departure for personal reflection and

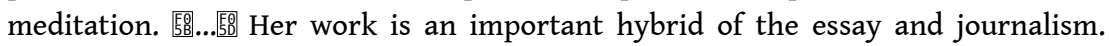

(58-59)

11 Before the backdrop of a more intimate knowledge of her entire oeuvre, a closer scrutiny of the title essay "Slouching Towards Bethlehem" will reveal that Didion does much more than describe and comment on what she witnesses at Haight-Ashbury in "the cold late spring of '67" (Slouching 84, 85, 112), as argued, for example, by Henderson (102), and parroted by Loris (100).

William Butler Yeats' poem “The Second Coming” serves as an epigraph to Slouching Towards Bethlehem and, obviously, also provided its title. The poem, written in 1919, draws a horrifying and repulsive picture of destruction, disintegration, and anarchy. A bloody struggle, "the blood-dimmed tide," unhinges the old order, inducing the reversal, or rather annihilation, of fundamental ethical categories: "The ceremony of innocence is drowned; / The best lack all conviction, while the worst / Are full of passionate intensity." Yeats was concerned with actual political revolutions and uprisings, aware that they also involved ethical upheaval. Among other allusions, the poem also resonates the Easter Uprising of 1916, which preshadowed Irish independence. And in this context, Yeats envisions the history of his native Ireland as culminating in a "Second Coming." He does not perceive the savior's reappearance; he sees instead a "rough beast." This centaur-like mixture between animalistic, instinctdriven body and a head guided by reason, whose gaze is "blank and pitiless," slouches slowly but steadily towards Bethlehem/Dublin/San Francisco, "waiting to be born." Didion observes the Black and Tans moving in the streets rather than the flower 
children's parades: the beast is slouching. De Valera's resurrection of Ireland becomes the prophecy of the IRA's "activities." In direct opposition to the Christian concept of "paradise regained" the poem evokes a pessimistic, frightening Cassandra-like prophecy of apocalypse dawning. Taking up Yeats' poem, Didion intones her undercurrent of fear that America is falling apart, and that a beast is waiting to be born. She anticipates Norman Mailer's chronicles in Armies of the Night of October '67, which culminate in analogous images. America, "now a beauty with a leprous skin," is "heavy with child," and Mailer, too, had fearfully wondered: "she will probably give birth, and to what?". This is, indeed, "The Metaphor Delivered" (Mailer 320 ).

Didion finds that particularly the first three lines and line fifteen of Yeats' poem "have been my points of reference," the only images "against which much of what I was seeing and hearing and thinking seemed to make a pattern" ("A Preface" xiii): "Turning and turning in the widening gyre / The falcon cannot hear the falconer; / Things fall

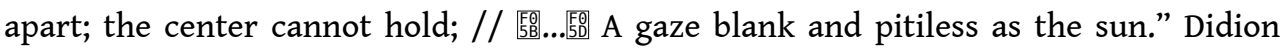
senses a continuous process of disintegration of her social reality; society seems to be falling apart into singular atoms, losing all internal cohesion. This loss of a solid center triggers a quasi-therapeutic writing process, as Didion puts it, so as to "come to terms with disorder" (xiv). In "A Preface" Didion, describing herself as "so physically small, so temperamentally unobtrusive, and so neurotically inarticulate" (xvi), points out that "whatever I do write reflects, sometimes gratuitously, how I feel" (xv). Gin-and-hotwater plus Dexedrine aside, "working did to the trouble what gin did to the pain" (xvi). For the "thirty-four-year-old woman with long straight hair and an old bikini bathing suit and bad nerves" (The White Album 135), her literary writing is the only way to soothe the confusion and agony she has inescapably fallen victim to. And those three Yeatsian images help her form a pattern to organize and make sense of her distressing experiences. Physical reality and psychological space blend into a metaphorical landscape.

One of the title essay's dazzling determining characteristics is the congruence of structural form and thematic essence. Reminiscent of John Dos Passos' montage technique, Didion illustrates her argument through forty-five narrative elements, sometimes a scene, sometimes a sketch or a tableau. The first two paragraphs preceding the Haight-Ashbury kaleidoscope establish a synopsis, and the first sentence is already programmatic or repetitive: "The center was not holding" (84). Just as the text splits up into numerous disconnected atomic fragments, so does-and that is Didion's overriding thesis and theme-American society as she perceives it. American society is deeply involved in an incessant process of disintegration. Key terms of the précis are thus primarily terms of centrifugality: "missing" (five times), "misplaced," "abandoned," and "moved on," culminating in the diagnosis: "we had aborted ourselves and

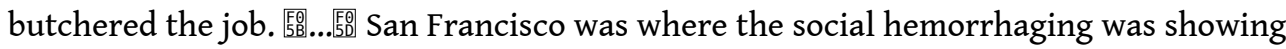
up" (84-85). Didion uses the example of the flower children's drifting through a timeless vacuum of synthetic hallucinogenic worlds in all forty-five scenes or tableaux to illustrate the social bleeding white, the ethical sell-out. "Turning and turning in the widening gyre," the communally oriented individual has been replaced by the contemporary solipsist, lacking direction, orientation, responsibility, and social Eros: “'We're just gonna let it all happen,' Jeff says. 'Everything is in the future, you can't preplan it"' (92). Steve says: "This chick tells me there's no meaning to life but it doesn't matter, we'll just flow right out." Asked "what it is that is supposed to happen," he answers: "I don't know. Something. Anything" (98). And Vicki "guesses maybe she will 


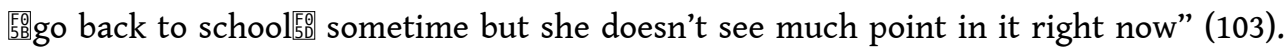
Max sums it all up: "If it happens, it happens. If it doesn't, it doesn't. Who cares. Nobody cares" (117).

\section{4. "The future always looks good in the golden land"}

Whereas American lore had provided the long cherished ideal of the successful, committed man, well geared to the teleological world view, Didion sees a young generation, allegedly the country's promising future, which is predominantly egocentric, lacking in drive, and falling free in the vortex of self-devouring consumption. As Officer Gerrans, known as the local zealot in Haight, puts it in an equally circular manner where form meets function: "I would say the major problems

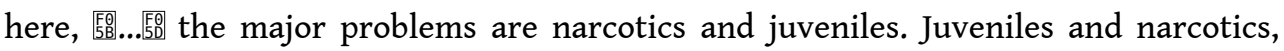
those are your major problems" (93). The helpless attempt to define the self leads entirely via ex negativo expressions of triumph over "don'ts" (88), that is, the disregard and dismissal of social norms and values, yet without the ability to form an adequate alternative model. Joan Didion presents to her readers a Haight-Ashbury drifting between psychedelics' escapades, "teenage evangelism," rock concerts, Zen-Buddhism, and macrobiotic food, culminating in the question: how many flavors can you detect in a single grain of rice (116)?

16 "The falcon cannot hear the falconer," America's youth is no longer embedded in the idealized structure of the nuclear family, which was meant to function as a centripetal force, but drifts in a clear state of atomization in a vacuum of aimlessness. Without "road holding," without home, past or future, they give in to the current of a drug induced maelstrom of nightmares and phantom existences of "somebodyssomewheres-somehows-and sometimes," which are the constitutive parts of most of the conversations Didion reports. The Puritan community had defined the center as a determining element of the "tight knit community," building "the city upon the hill." The initial survival of the settlers had been dependent on the internal cohesion of the congregation, and then transformed into a constitutive element of American ideas and oratory. Now, official rhetoric resembles more a mantra-like singsong than a lived reality; historical change has led to internal fragmentation and dissipation, rhetoric and reality have been disconnected. The social glue is finally dissolving. Didion's always recurring terms of analysis are "atomization" and "disorder." She seems to be reminding us that a generation which does not know its past, has no future.

In "Some Dreamers of the Golden Dream" we find an exemplary addendum to this point of criticism, which is one of Didion's main literary themes:

The future always looks good in the golden land, because no one remembers the past. Here is where the hot wind blows and the old ways do not seem relevant ${ }_{56}$.... Here is the last stop for all those who come from somewhere else, for all those who drifted away from the cold and the past and the old ways. Here is where they are trying to find a new life style, trying to find it in the only places they know to look: the movies and the newspapers. (Slouching 4)

Again, Didion uses the myth of the West with all its canonized connotations, to debunk the reality it has become: "PRIVATE ROAD / BELLA VISTA / DEAD END" (26). The West turns out to be a present which is constantly negotiated with the myth of the past, and thus not a geographical reality, but rather an emotion, an attitude, and, in combination also with her own emotional state, a complicated mental landscape. ${ }^{3}$ Didion ascertains, 
and the reference to Spengler is obvious: "the West declined in the spring of '67" (108). Could we imagine a more precise and poignant post mortem for one of America's fundamental premises?

"Objective, hard facts" serve to illustrate a visceral undercurrent of fear, a numinous feeling of anxiety which Didion can only articulate by instrumentalizing observed "facts" in her idiosyncratic (re)presentation and symbolic Überhöhung. The West is no longer the golden promise, Horace Greeley would no longer dare to voice the famous or infamous battle-cry "Go West, Young Man". “Here, 痗...爁 where we run out of continent" (172), the end of the dream seems to be sealed: in view of the social anemia, the American Dream is unmasked as bereft of content, "the social hemorrhaging was showing up" (85). The described present triggers a frightened anticipation of the future, physical geographical space has turned into a mental chart. Didion's fearful and terrified diagnosis and prognosis is: "Things fall apart; the center cannot hold."

Didion follows the same strategy of paralleling her "realistic reportage" on "the State of the Nation" with her own mental/psychological situation some thirty-five years later in Where I Was From. Triggered by the death of her mother, the author remembers her personal past and that of her home state, California, wondering "who will look out for me now, who will remember me as I was, who will know what happens to me now, where will I be from" (204). California has remained impenetrable, a "wearying enigma" which she confronts yet again (38).

21 Remembering a speech she gave at her eighth-grade graduation on "Our California Heritage," she realizes that certain aspects of "Our California Heritage" "did not add up." In her youth, she had still been singing a hymn to progress and the American belief in a teleological movement towards perfection, success, and happiness, embodied in "the West." She had praised the past accomplishments only in order to look ahead and call for additional effort: "We can't stop and become satisfied and content. We must live up to our heritage, go on to better and greater things for California." Didion's next sentence, after having quoted her own speech script, reads: "That was June 1948" (17). And the irony is obvious: in August 1948, the United States would drop the two atomic bombs on Hiroshima and Nagasaki, and the world would be changed forever.

"I began trying to find the 'point' of California, to locate some message in its history" (17), she writes. "A good deal about California does not, on its own preferred terms, add up" (19)-land development, railroad construction, irrigation and water rights, subsidized crops, land ownership-all these themes Didion unravels, and her reports bring to the fore that California is and always has been relying heavily on federal money, which is "so seemingly at odds with the emphasis on unfettered individualism that constitutes the local core belief" (23). Didion sees contradictions everywhere, cites "facts," and tries to trace the continuous attempt to invent California on the basis of the myth of the Westward-moving settler, "the crossing story" (30), a "master odyssey" of those who cut loose, abandoned their previous lives, and were reborn in the wilderness during their quest, seeking redemption: "There are many connections in California life, yet [...] not much connects" (61).

This time, it is not Haight-Ashbury, but Lakewood, which serves Didion as one seismograph for social disequilibrium. Much of the California landscape "has tended to present itself as metaphor, even as litany" (66). Lakewood, once a model suburb of Los Angeles, also undergoes a process of degeneration and fragmentation. Here, too, the 
center cannot hold. In the late 1960's, this new development had grown as the typical middle-class "America U.S.A." area:

These World War Two and Korean War veterans and their wives who started out in Lakewood were, typically, about thirty years old. They were, typically, not from California but from the Midwest and the border South. They were, typically, bluecollar and lower-level white collar. They had 1.7 children, they had steady jobs. Their experience tended to reinforce the conviction that social and economic mobility worked exclusively upward. (106)

By the late 1990s, the situation has changed dramatically. The community is on the downspin, the McDonnell Douglas plant is gradually being closed down, thousands of jobs on which the community had depended are lost, and then there is that one incident in March 1993, which Didion describes, where the "social hemorrhaging" is showing yet again ("Slouching" 85). Nine High School students were arrested and requests were made that charges be brought on

ten counts of rape by intimidation, four counts of unlawful sexual intercourse, one count of forcible rape, one count of oral copulation, and one count of lewd conduct with a minor under the age of fourteen. (110)

Didion also reports cases of assault, burglary, theft, and felony arrests. Where she sees a pattern, the people in Lakewood decided to treat the cases as individual quirks, inconsistent with their preferred self-image. Didion proves the "tacit dissonance" at the center of every moment in Lakewood (113). She quotes a high school student saying: "They pass out condoms, teach sex education and pregnancy this, pregnancy that, but they don't teach us any rules" (111); the parallels to Haight are obvious. Turning and turning, the falcon cannot hear the falconer. The beast is still slouching, the discrepancy between mythologized California and dismal reality becomes obvious once more:

Good times today and better times tomorrow were supposed to come with the territory, roll in with the regularity of the breakers [...]. Good times were the core conviction of the place, and it was their only gradually apparent absence, in the early 1990 's, that began to unsettle California in ways that no one exactly wanted to plumb. (129)

In retrospect, Didion contrasts the/her past, characterized by an idealized belief in California and its promise, and the state of sorrow and disillusionment the nation/she has reached now. Now, hope, promise, and stability have been replaced by a distanced disillusionment: "the dream of America, the entire enchantment under which I had lived my life-began to seem remote" (220).

All her observations in Where I Was From, which cannot escape the accusation of being highly eclectic, serve to illustrate that her own, personal loss of a vital part of her identity has caused just as much irritation, insecurity and seemingly irreparable change than the historical process has wreaked on the idealized image of the American West. The West-as-myth, with all the positive connotations attributed for decades, is employed by Didion to reminisce about her childhood and youth, and to express the shaken-ness she experiences now after her mother's demise; now that "the West" and "California" no longer comply with her memory, with the comforting ideal once cherished and currently sorely lacking. She realizes that "this is a country at some level not as big as we like to say it is" (4). 


\section{5. "There was Wayne"}

In her 1965 essay "John Wayne: A Love Song," Didion had focused on one single emblematic character in order to sketch and revitalize an image opposite to that of the chaotic present as she perceived it then and still perceives it now, thus reinforcing yet another stereotypical image of the West, the cowboy. In 1965, she had still been able to hold on to symbols of stability and order which provided her with the comfort she required.

"There was Wayne": Wayne was the ultimate symbol of stability and inner integrity, intertwined with the Western cowboy-as-hero. His steadfast dedication to "the code" defined his peculiar, strong heroism. Wayne was the national hero who not only represented orientation and ordering structure, but who also became the authentic, virtuous American ideal. "There was Wayne": Wayne's world was ordered, hierarchically organized and paternalistic; "he had a sexual authority so strong that even a child could perceive it" (Slouching 30). He made the decisions ("When John Wayne spoke, there was no mistaking his intensions" [30]), and he provided security and comfort. For his girl, he built the house in the midst of the pastoral idyll, "at the bend in the river, where the cottonwoods grow" (30).

Reality for Didion was and still is characterized by "venality and doubt and paralyzing ambiguities." She set against this the unarticulated American dream of freedom, independence, and a world of codified norms and values: "a place where a man could move free, could make his own code and live by it" (31). Here, "the center can hold." Wayne's cragged face could be on Mount Rushmore.

\section{Imagined Places: "where will I be from"}

During a private dinner with Wayne, Didion relates, the melody of promise, which he embodied, is audible:

And in a world we understood early to be characterized by venality and doubt and paralyzing ambiguities, he suggested another world, one which may or may not have ever existed but in any case existed no more: a place where a man could move free, could make his own code and live by it; a world in which, if a man did what he had to do, he could one day take the girl and go riding through the draw and find himself home free, 監...區 there at the bend in the bright river, the cottonwoods shimmering in the early morning sun. (30-31)

It is this other world of the past which epitomizes Didion's retrogressive utopia. ${ }^{4}$ It is a world which "may or may not have ever existed," yet it lived on as an imagined wish, desire or mournful longing, and in comparison to the reality as she perceived it caused her Weltschmerz. In Where I Was From, the loss of place is the loss of identity. With the death of her parents, protection, safety, and a sense of shared memories of a past are irretrievably lost: "[...] where will I be from" (204). Her dreams had equated place-as emotional space-with security and comfort: beautiful nature with sunshine, softly flowing water and shadowy trees, and not a place of Santa Anas, storm floods and frightening darkness. The Santa Ana is a guiding symbol throughout Didion's work. In Slouching, the wind figures most prominently in "Some Dreamers of the Golden Dream":

[...] devastated by the hot dry Santa Ana wind that comes down through the passes at 100 miles an hour and whines through the eucalyptus windbreaks and works on 
the nerves. 熙...医 It is the season of suicide, and divorce and prickly dread, wherever the wind blows. (3) Robinson Jeffers speaks about the west wind which "throws with the landward spray / Dreams on our minds, and a dreamy unrest" (Jeffers 51), Didion reinforces the symbol: psychological tension and distress affect not only herself, but the California people, thus rationalizing behavioral patterns and reactions, becoming part of "the Big Empty." Early on in Where I Was From, Didion again links the nervous restlessness of the Western pioneers with her own nervousness, which, as family lore has it, she has inherited from her-allegedly eccentric-grandmothers (Where I Was From 9-13):

They were women, these women in my family, without much time for second thoughts, without much inclination toward equivocation, and later, when there was time or inclination, there developed a tendency, which I see as endemic, toward slight and major derangements, apparently eccentric pronouncements, opaque bewilderments and moves to places not quite on the schedule. (7-8)

In clear-cut contrast, it is at the bend in the river, in the early morning sun, that Didion sensed peace, happiness and hope; the man in front on the saddle, riding the horse, provided safety, comfort, simplified order, and clear directions. Despite recent criticism that this beautification of the myth and "the code" simultaneously constitutes a beatification and thus a "postmodern no-no"-due to the over-emphasis of the good over the multitude of the despicable bad inherent in the concepts-for a writer such as Joan Didion, this criticism was pointless. As she herself puts it in Where I Was From:

Such calls to dwell upon the place and its meaning (and, if the meaning proved intractable, to reinvent the place) had been general in California since the first American settlement, the very remoteness of which was sufficiently extreme to raise questions about why one was there, why one had come there, what the voyage would ultimately mean. (28-29)

Didion's recent writing is not in the least jingoistic, quite the reverse: in Where I Was From, she reveals the dark, harsh, and morally ambiguous elements of the so-called crossing stories, and questions the concept of rebirth and redemption. Didion quotes extensively from diaries, for example that of Bernard Reid, who chronicled his emigration Westward in the late 1840s and told the story that one day, on their journey, they found a young woman, Miss Gilmore, and her sick brothers at a deserted wagon, with no oxen. Miss Gilmore's parents had died of cholera, and the wagon train had moved on without them, deserting them in a truly inhospitable and dangerous environment with the only hope that another train with oxen to spare might pass by and take them along. Didion comments:

The redemptive power of the crossing was, nonetheless, the fixed idea of the California settlement, and one that raised a further question: for what exactly, and at what cost, had one been redeemed? When you jettison others so as not be "caught by winter in the Sierra Nevada mountains," do you deserve not to be caught? When you survive at the cost of Miss Gilmore and her brothers, do you survive at all? [...] From what exactly was "the break" or "the void" or "the cutting clean" to have redeemed them? [...] And the related question: for what were they to have been redeemed? [...] What exactly was our heritage? Remember, as Virginia Reed wrote to her cousin, never take no cutoffs and hurry along as fast as you can. (36-37; 159-60)

For her own personal story, the West of her mental and psychological landscape needed/needs an icon of order and stability in view of observed disorder and loss. Therefore, for her, for her view on America, and her interpretation of observed reality,

European journal of American studies, 6-3 | 2011 
there once was-and maybe still is-reassurance and comfort in what Wayne personified: "There was Wayne." Marion Morrison had been "the perfect mould" in which "might be poured the inarticulate longings of a nation wondering at just what pass the trail had been lost" (31). Nostalgically speaking, Wayne would not have led her to Haight-Ashbury in the "cold late spring of '67" ("Slouching" 84) but to "the bend in the river, where the cottonwoods grow" ("John Wayne" 30). And isn't it pretty to think so?

\section{BIBLIOGRAPHY}

Anderson, Chris. "The Cat in the Shimmer." Style as Argument: Contemporary American Nonfiction. Ed. Anderson. Carbondale: Southern Illinois UP, 1987. Rpt. in Felton, The Critical Response 51-64.

Bahners, Patrick. "Gespenster: Joan Didions abweichende Meinung zum Fall Terri Schiavo" ("Ghosts: Joan Didion's diverging opinion on the case of Terri Schiavo"). Frankfurter Allgemeine Zeitung 4 Aug. 2005: 31.

Baudrillard, Jean. America. Trans. Chris Turner. New York: Verso, 1988.

Brady, Jennifer. "Points West, Then and Now: The Fiction of Joan Didion." Contemporary Literature 20 (1979): 452-70.

Didion, Joan. After Henry. New York: Simon and Schuster, 1992.

-_- Run River. New York: Simon and Schuster, 1963.

_-_. Slouching Towards Bethlehem. 1968. New York: Farrar, Strauss and Giroux, 1999.

-—- Where I Was From. New York: Alfred A. Knopf, 2003.

-—- The White Album. New York: Simon and Schuster, 1979.

Felton, Sharon. The Critical Response to Joan Didion. Westport, CT: Greenwood, 1994.

---. Introduction. Felton, The Critical Response 1-11.

Geherin, David J. “Nothingness and Beyond: Joan Didion's Play It As It Lays.” Critique 16.1 (1974): 64-78.

Harrison, Barbara Grizzuti. "Joan Didion: Only Disconnect.” Off Center: Essays by Barbara Grizzuti Harrison. New York: Dial Press, 1980. 113-24.

Henderson, Katherine Usher. Joan Didion. New York: Frederick Ungar, 1981.

Jeffers, Robinson. "Epilogue." The Collected Poetry of Robinson Jeffers. Stanford: Stanford UP, 1963. 51.

Kakutani, Michiko. “Joan Didion: Staking Out California." New York Times Magazine 10 June 1979: 44-50. 
Kühnel, Walter. "'I Tell You This Neither in a Spirit of Self-Revelation Nor as an Exercise in Total Recall': John Wayne, the Man Whom German Intellectuals Love(d) to Hate." Popular Culture in the United States. Ed. Peter Freese and Michael Porsche. Essen: Die Blaue Eule, 1994. 213-34.

Loris, Michelle Carbone. Innocence, Loss, and Recovery in the Art of Joan Didion. New York: Peter Lang, 1989.

Maddocks, Melvin. "Her Heart's with the Wagon Trains." Christian Science Monitor 16 May 1968: 11.

Mailer, Norman. The Armies of the Night. New York: Penguin, 1968.

Meyer, Gerald J. “From Hippies to Hawaii.” Des Moines Sunday Register 26 May 1968: 4C.

Michaels, Leonard, David Reid, and Raquel Scherr, eds. West of the West: Imagining California. San Francisco: North Point P, 1989.

Stout, Janis P. Strategies of Reticence: Silence and Meaning in the Works of Jane Austen, Willa Cather, Katherine Anne Porter, and Joan Didion. Charlottesville: UP of Virginia, 1990.

Turner, Frederick Jackson. "The Significance of the Frontier in American History.” Annual Report of the American Historical Association (1893): 199-227. Rpt. in An American Primer. Ed. Daniel Boorstin. Chicago: U of Chicago P, 1966. 542-70.

Yeats, William Butler. "The Second Coming." 1920. Rpt. in Didion, Slouching. n.pag.

\section{NOTES}

1. Michelle Carbone Loris, in Innocence, Loss, and Recovery in the Art of Joan Didion, reaches similar conclusions, yet emphasizes above all the biblical references and allusions in Didion's writing. See also Michiko Kakutani, “Joan Didion: Staking Out California” 44-50.

2. See particularly early reviews, e.g. Gerald J. Meyer, "From Hippies to Hawaii," or Melvin Maddocks, "Her Heart's with the Wagon Trains." This misconception of categorizing Didion as a New Journalist has not been rectified, as Patrick Bahners to my dismay proved in a 2005 article in Die Frankfurter Allgemeine Zeitung entitled "Gespenster: Joan Didions abweichende Meinung zum Fall Terri Schiavo“ (“Ghosts: Joan Didion's diverging opinion on the case of Terri Schiavo"): "Sie protokolliert und montiert, kommentiert nur durch das Arrangement der Fakten und Zitate und durch knappste, wegwerfende Schlussbemerkungen" ("She records and assembles, comments simply by arrangement of facts and quotations and through briefest dismissive final remarks") (31; my translation).

3. An interesting detail should not be overlooked at this point: it is most certainly telling that Didion ends the essay with the Michael episode. The guardian angel of God's people (Daniel 10.21), the leader of the heavenly troops of Angels fighting Satan (Revelation 12.7), is here a three-year-old toddler. And it is a toddler who does not yet speak (95), but displays a thoroughly destructive character: he starts open fires and chews electric cables. He provides the final chord for the frightened, pessimistic report from Haight-Ashbury.

4. It reappears, particularly in her early work. See for example in Run River: "[...] confident that the next party would reveal to her the just-around-the-corner country where the green grass grew" (36-37). 


\section{ABSTRACTS}

Joan Didion's depiction of the American West and California is colored by an idiosyncratic sensitivity to her surroundings, intertwined with a sentimental-retrogressive image of the nature, history, character, and meaning of the West as a cultural topos. Her New Journalism-like observations of California are always closely linked to her own self and psyche, are seismographs of her own confusions, of moments of disorientation, insecurity, and loss. Didion is therefore one of those exceptional writers, who, in her fictionalized reportages, comments on American reality, ideas, and her own predicament. Identity and landscape fuse into an auto-psychoanalysis, which at the same time reveals a great deal about the American condition, its constantly strained relationship between rhetoric or auto-mythology and lived reality. This article draws primarily on Slouching Towards Bethlehem (1968) and Where I Was From (2003), but also on After Henry (1992) and The White Album (1979), to illustrate these points.

\section{INDEX}

Keywords: After Henry, auto-psychoanalysis, California, mental landscape, New Journalism, retrogressive Utopia, Slouching Towards Bethlehem, The White Album, West as myth, Where I Was From, "spirit of place"

\section{AUTHORS}

\section{EVA-SABINE ZEHELEIN}

Friedrich-Wilhelms-University Bonn, Germany 